\title{
Distribution of Protein Kinase C-like Immunoreactive Neurons in Rat Brain
}

\author{
Naoaki Saito,' Ushio Kikkawa, ${ }^{2}$ Yasutomi Nishizuka, ${ }^{2}$ and Chikako Tanaka' \\ Departments of ${ }^{1}$ Pharmacology and ${ }^{2 B}$ Biochemistry, Kobe University School of Medicine, Kobe 650, Japan
}

\begin{abstract}
Distribution of protein kinase $\mathrm{C}$ in the CNS of rat is presented based on immunohistochemical analysis with monoclonal antibodies against this protein kinase. Protein kinase C-like immunoreactivity was discretely localized and associated with neurons. Most, if not all, glial cells were not significantly stained. The greatest density of the immunoreactive material was seen in the following regions: the olfactory bulb (external plexiform layer), olfactory tuberculum, anterior olfactory nucleus, cerebral cortex (layers I and IV), pyriform cortex, hippocampus (strata radiatum and oriens), amygdaloid complex (central and basolateral nuclei), cerebellar cortex (molecular layer), dorsal cochlear nucleus, nucleus spinal tract of the trigeminal nerve, and dorsal horn of the spinal cord (substantia gelatinosa). Image analysis revealed that the regional distribution of the protein kinase C-like immunoreaction generally agreed with that of phorbol ester-binding sites. Immunoreactive perikarya were found in the following areas: the cerebral cortex (layers $\mathbf{V}$ and VI), caudate putamen, hippocampus, thalamus, amygdaloid complex, medial and lateral geniculate nucleus, superior colliculus, cerebellar cortex, nucleus spinal tract of the trigeminal nerve, dorsal cochlear nucleus, and dorsal horn of the spinal cord. Intense protein kinase $\mathrm{C}$-like immunoreactivity in the neuron was observed both in the membrane and cytoplasm of the perikarya, dendrites, axons, and axon terminals, while weak immunoreaction was seen in the nuclei but almost never in the nucleoles. A map of protein kinase C-containing neurons was constructed. Such an uneven distribution in the brain suggests that this enzyme may play roles in controlling neuronal function in the areas noted.
\end{abstract}

Protein kinase $\mathrm{C}$ has been implicated as a common mechanism for the transduction of various extracellular signals into the cell to control many physiological processes (for reviews, see Nishizuka, 1984a, b, 1986). In the presence of both $\mathrm{Ca}^{2+}$ and phospholipids, this protein kinase is activated by 1,2-diacylglycerol, which transiently appears in the cell membrane as a consequence of receptor-mediated hydrolysis of inositol phospholipids (Takai et al., 1979; Kishimoto et al., 1980). Protein kinase C is known to be ubiquitously distributed in tissues. In particular,

Received May 4, 1987; revised July 16, 1987; accepted July 20, 1987.

This work was supported by research grants from the Scientific Research Fund of Ministry of Education, Science and Culture and the Ministry of Health and Welfare, Japan; the Muscular Dystrophy Association; the Yamanouchi Foundation for Research on Metabolic Disorders; the Merck Sharp \& Dohme Research Laboratories; the Biotechnology Laboratories of 'lakeda Chemical Industries; the Ajinomoto Central Research Laboratories; and the Meiji Institute of Health Sciences. We wish to thank Y. Ishida for preparing illustrations of the brain map.

Correspondence should be addressed to Chikako Tanaka at the above address. Copyright (C) 1988 Society for Neuroscience $0270-6474 / 88 / 020369-14 \$ 02.00 / 0$ high amounts of this enzyme are present in the CNS (Kuo et al., 1980; Minakuchi et al., 1981; Kikkawa et al., 1982). Recent immunohistochemical analysis with polyclonal antisera against protein kinase $\mathrm{C}$ has shown that its intracellular distribution varies with cell type (Girard et al., 1985; Shoji et al., 1986; Wood et al., 1986). It has been clarified by complementary DNA analysis that multiple subspecies of this enzyme may exist in mammalian brain tissues (Coussens et al., 1986; Parker et al., 1986; Knopf et al., 1986; Makowske et al., 1986; Ono et al., 1986a, b; Ohno et al., 1987). More recently, an apparently homogeneous preparation of rat brain protein kinase C (Kikkawa et al., 1986) was shown to be further resolved into 3 distinct fractions, types I, II, and III, upon hydroxyapatite column chromatography (Huang et al., 1986; Kikkawa et al., 1987). The amino acid sequences of the 3 fractions were identified by comparison with the enzymes, which were separately expressed in COS cells transfected by the respective complementary DNAs (Kikkawa et al., 1987; Ono et al., 1987). In a preceding report (Kitano et al., 1987), 3 monoclonal antibodies-CKI-33, CKI-97, and C.KII-90 - were described that were raised against a mixture of the subspecies of rat brain protein kinase $C$. In the hope of clarifying the functional role of protein kinase $C$ in the nervous system, we have made a preliminary survey of the distribution of this protein kinase in both brain and spinal cord of rats. Comparison of this enzyme pattern will also be made with that determined by phorbol ester binding.

\section{Materials and Methods}

Preparation of monoclonal antibodies. Protein kinase $\mathrm{C}$ was purified from the soluble fraction of the rat brain (Kikkawa et al., 1986), and 3 clones of monoclonal antibodies against the enzyme (CKI-33, CKI-97, and CKII-90) were prepared and the indetailed characteristics examined (Kitano et al., 1987). In the present studies, a mixture of the 3 antibodies was employed because the combined antibodies exhibited much stronger binding activity to protein kinase $C$ than any of the antibodies alone, as described previously (Kitano et al., 1987).

Preparation of tissues. Wistar rats weighing 120-170 gm were anesthetized with pentobarbital $(40 \mathrm{mg} / \mathrm{kg}$, i.p.) and perfused through the left ventricle at a flow rate of $15 \mathrm{ml} / \mathrm{min}$. The blood was removed with $30 \mathrm{ml}$ of $0.9 \% \mathrm{NaCl}$ at $4^{\circ} \mathrm{C}$, and the brain was perfused at $4^{\circ} \mathrm{C}$ with 200 $\mathrm{ml}$ of a fixative containing $4 \%$ paraformaldehyde (FA), $0.2 \%$ picric acid (PA), and $0.5 \%$ glutaraldehyde in $0.1 \mathrm{M}$ phosphate buffer (PB, $\mathrm{pH} 7.4)$. The brain was dissected, immersed for $48 \mathrm{hr}$ in the postfixative containing $4 \% \mathrm{FA}$ and $0.2 \% \mathrm{PA}$ in $\mathrm{PB}$ at $4^{\circ} \mathrm{C}$, washed with $30 \%$ sucrose in $\mathrm{PB}$, and then cut on a cryostat or vibratome into frontal sections ( 20 $\mu \mathrm{m})$. These sections were dipped directly in $0.1 \mathrm{M}$ PBS containing $0.3 \%$ Triton X-100 (PBS-T) and were subsequently washed with the same buffer for at least $4 \mathrm{~d}$ at $4^{\circ} \mathrm{C}$ before use.

Immunohistochemical staining. The following steps were carried at $4^{\circ} \mathrm{C}$ unless otherwise indicated. The sections were incubated for $10 \mathrm{~min}$ with $0.3 \% \mathrm{H}_{2} \mathrm{O}_{2}$ in PBS-T to inhibit the endogenous peroxidase and for 20 min with $3 \%$ normal goat serum (NGS) in PBS-T to block the nonspecific binding sites of proteins. The sections were washed with 

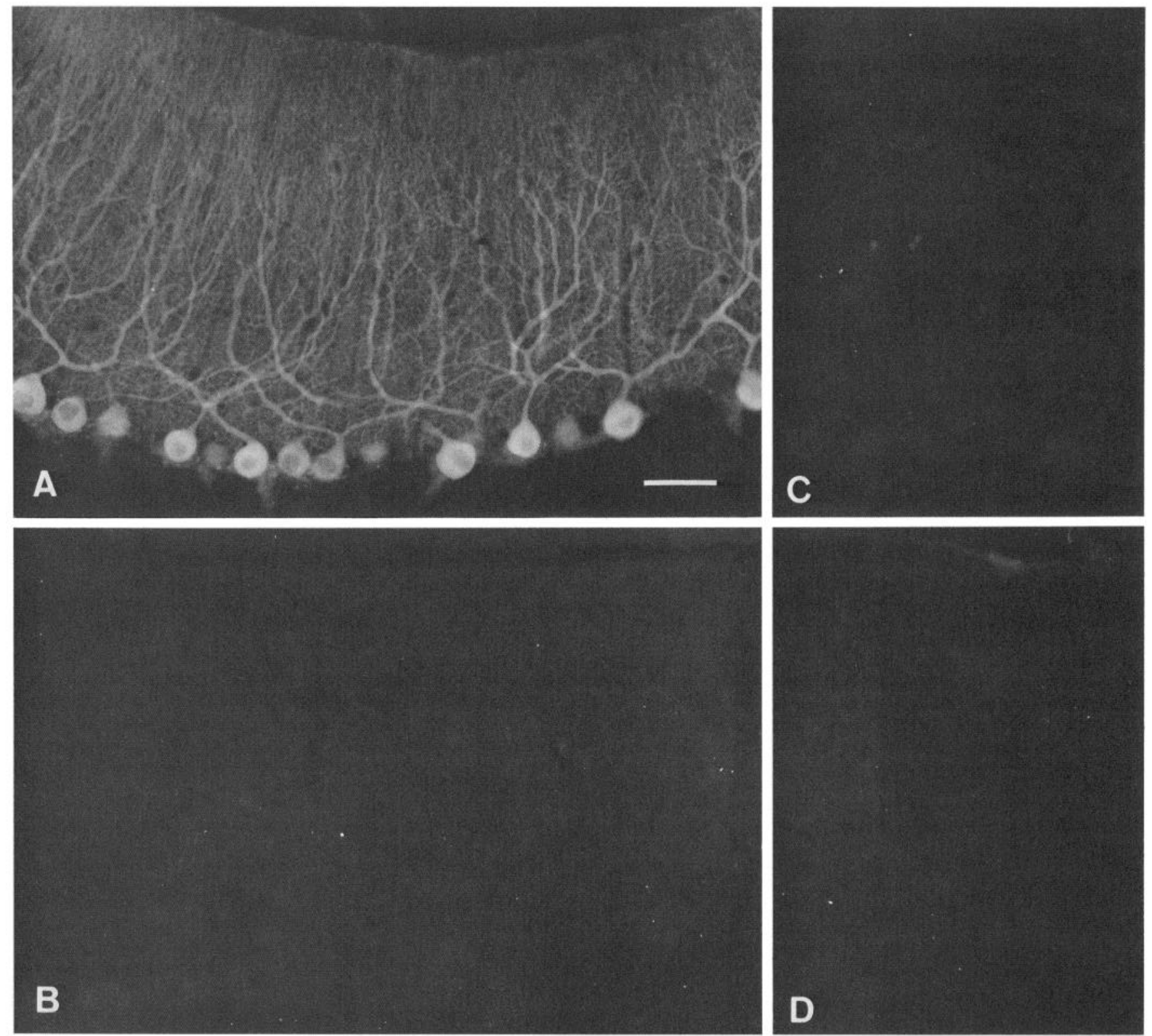

Figure 1. Absorption test of the monoclonal antibodies against protein kinase $\mathrm{C}$ in the immunohistochemical staining of sagittal sections of rat cerebellar cortex. $\times 25$. Intense immunostaining of the Purkinje cells is seen in the section immunostained with nontreated mixed monoclonal antibodies (final concentration, $1 \mu \mathrm{g} / \mathrm{ml})(A)$ but is completely abolished in the sections immunostained with preabsorbed monoclonal antibodies with purified C-kinase $(5 \mu \mathrm{g} / \mathrm{ml})(B)$, PBS containing Triton-X $(0.1 \mathrm{M}, \mathrm{pH} 7.4)(C)$, normal mouse IgG $(1 \mu \mathrm{g} / \mathrm{ml})$ instead of monoclonal antibodies (D). Scale bar, $100 \mu \mathrm{m}$.

PBS-T and incubated with 3 monoclonal antibodies against protein kinase C (CKI-33, CKI-97, and CKII-90) in PBS-T for $18 \mathrm{hr}$ to yield a final concentration of $1 \mu \mathrm{g} / \mathrm{ml} \mathrm{IgG}$. For peroxidase-antiperoxidase (PAP) immunostaining, the sections were washed again, incubated for $6 \mathrm{hr}$ with goat anti-mouse IgG (Miles), diluted 1:1000, washed, and then incubated with mouse PAP complex (Miles) diluted 1:5000 for 1.5 $\mathrm{hr}$. After rinsing 3 times, the preparations were reacted with $0.02 \% 3,3^{\prime}$ diaminobenzidine (DAB, Sigma) and $0.2 \%$ nickel ammonium sulfate in $50 \mathrm{mM}$ Tris- $\mathrm{HCl}(\mathrm{pH} 7.4)$ containing $0.005 \% \mathrm{H}_{2} \mathrm{O}_{2}$. The preparations were dehydrated and coverslipped with Entellan (Merck) for light microscopic observation. For the immunofluorescent study, the sections were washed again and then incubated for $2 \mathrm{hr}$ with fluorescein isothiocyanate-conjugated goat anti-mouse IgG (Miles) diluted 1:250. After rinsing 3 times, the sections were mounted in buffered glycerol for fluorescent microscopic observation.

Immunohistochemical control studies for the specificity were made by using PBS-T, normal mouse IgG, or the monoclonal antibodies which were preabsorbed with purified protein kinase C $(5 \mu \mathrm{g} / \mathrm{ml})$ instead of the monoclonal antibodies against protein kinase $\mathrm{C}$.

${ }^{3} \mathrm{H}-\mathrm{PDB} \mathrm{C}$ autoradiography of phorbol ester binding sites. ${ }^{3} \mathrm{H}$-phorbol 12,13-dibutyrate (PDBu) autoradiography was carried out by the method of Worley et al. (1986a). Briefly, Wistar rats weighing 120-170 gm were anesthetized, and the brain was perfused via the left ventricle with 50 mм sodium phosphate $(\mathrm{pH} 7.5) / 0.3 \mathrm{M}$ sucrose. The brain was dissected, cut on a cryostat at $7 \mu \mathrm{m}$, and mounted on gelatine-coated slides. The first section of 3 serial sections was fixed and immunostained with the monoclonal antibodies against protein kinase $C$ by the PAP method described above. The second section was incubated with $2.5 \mathrm{~nm}{ }^{3} \mathrm{H}-$ $\mathrm{PDBu}$ in $50 \mathrm{~mm}$ Tris- $\mathrm{HCl}$ buffer (pH 7.4) containing $100 \mathrm{~mm} \mathrm{NaCl}$ and $1 \mathrm{~mm} \mathrm{CaCl}$. Nonspecific labeling was examined on the third section by adding $1 \mu \mathrm{M}$ nonradioactive PDBu in the solution. After rinsing, the second and third sections were dried, attached to a Ultrofilm (LKB), and exposed for $7 \mathrm{~d}$ at $4^{\circ} \mathrm{C}$. The autoradiogram and immunostaining were analyzed on an IBAS II image analyzer (Zeiss). 


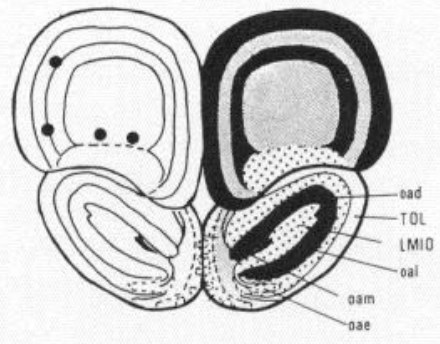

A
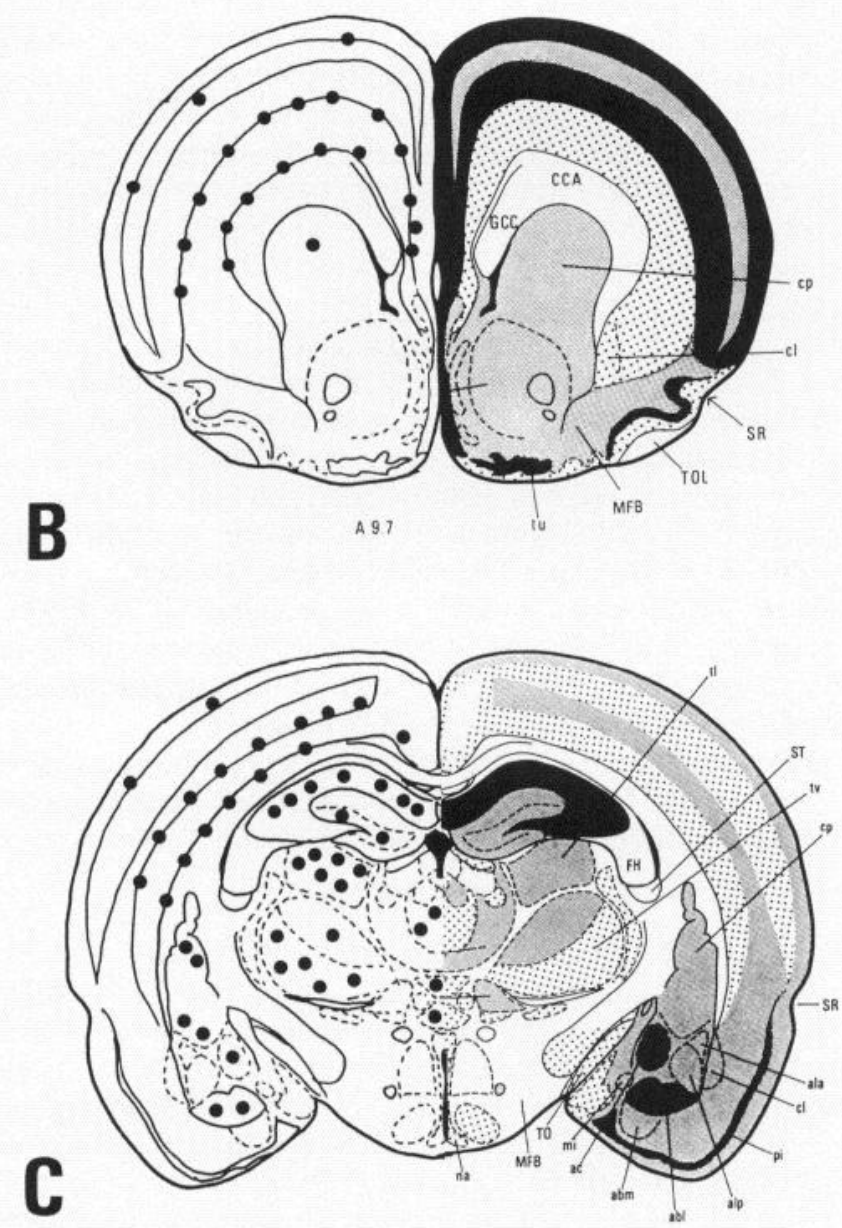
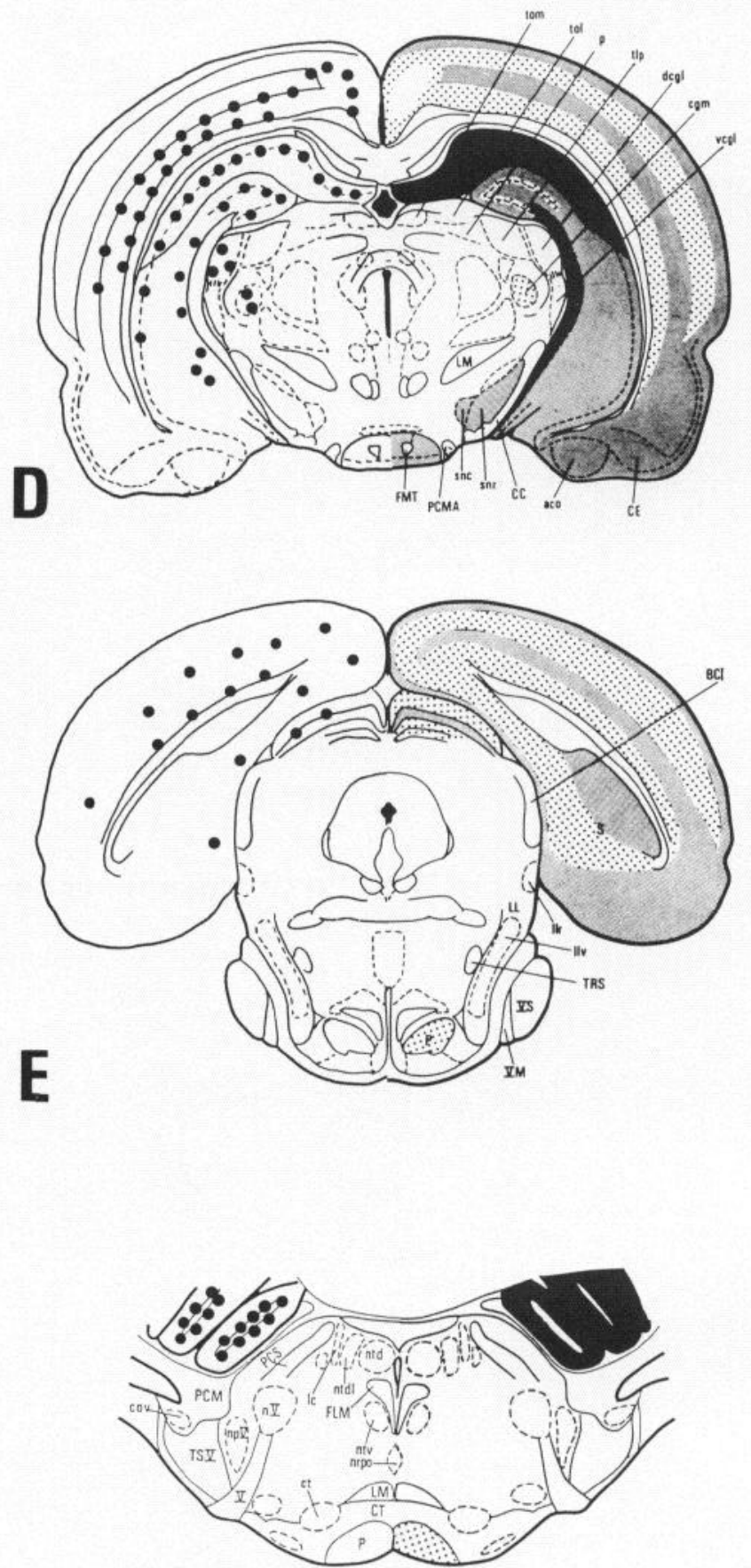

$\mathbf{F}$

Figure 2. Atlases of the distribution of protein kinase C-like immunoreactivity in the frontal diagrams from forebrain to midbrain of the rat which are drawn based on the frontal sections stained by peroxidase-antiperoxidase immunohistochemistry. Total density of the immunoreaction ( $\mathbf{n}$, high; on the right-hand side of the diagram (rostral; $A$ to caudal; $F$ ).

\section{Results}

Control studies for immunohistochemical staining with monoclonal antibodies against protein kinase $C$

The monoclonal antibodies produced a selective staining pattern in the various sections of the rat brain. CKI-97 produced intense staining, but CKI-33 or CKII-90 alone produced poor staining. A mixture of the 3 antibodies, however, exhibited more intense positive staining than CKI-97 alone. In the cerebellar section, all Purkinje cells showed protein kinase C-like immunoreactivity, which was much greater in the cytoplasm of perikaryon and dendrite than in the nucleus and very low in the 


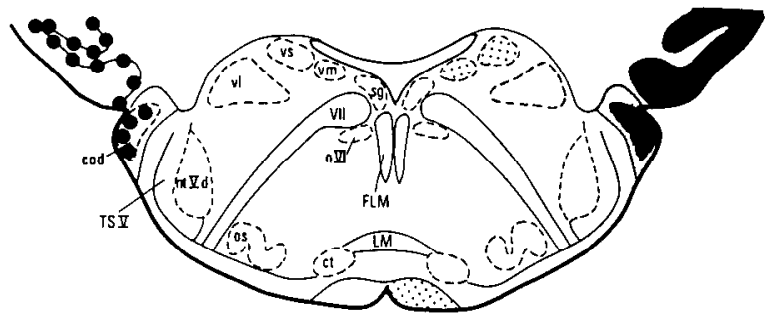

A

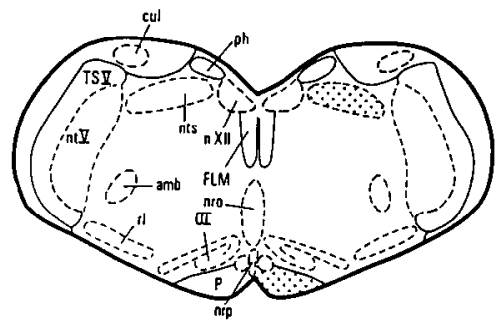

B

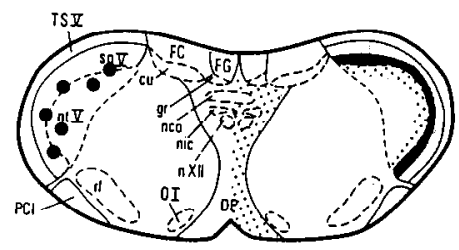

C
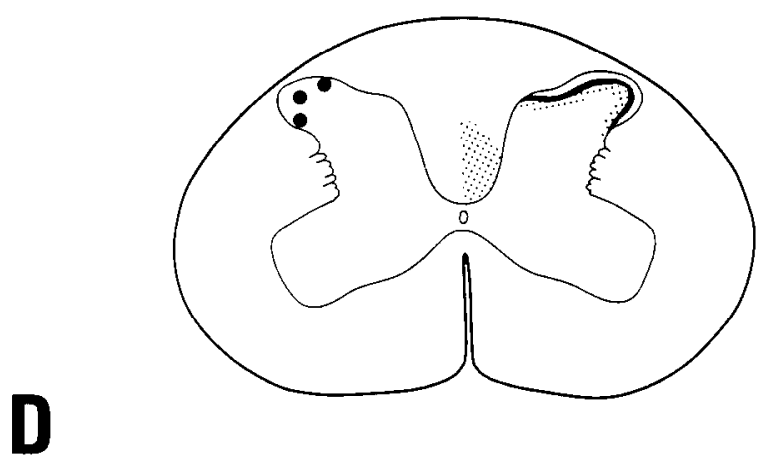

Figure 3. Atlases of the distribution of protein kinase C-like immunoreactivity in the frontal diagrams from hind brain to cervical spinal cord of the rat which are drawn based on the frontal sections stained by peroxidase-antiperoxidase immunohistochemistry. Total density of the immunoreaction $(\square$, high; $\square$, relatively high; 圈, relatively low; $\square$, low) is indicated on the left-hand side. Protein kinase C-positive peri- nucleolus (Fig. 1A). Preabsorption of the monoclonal antibodies with the purified protein kinase $\mathrm{C}(5 \mu \mathrm{g} / \mathrm{ml})$, however, completely abolished the immunoreaction in the section of cerebellum (Fig. $1 B$ ). Similarly, no staining was observed in the cerebellar sections when PBS-T (Fig. 1C) or normal mouse IgG (Fig. $1 D$ ) was used instead of the monoclonal antibodies. By absorption tests, the immunostaining in other brain regions shown in Figures 5-11 was also identified as protein kinase C-like immunoreactivity (data not shown).

\section{General distribution of protein kinase C-like immunoreactivity}

The density of protein kinase C-like immunoreactivity was greatest in the following regions; the olfactory bulb (external plexiform layer), olfactory tuberculum, anterior olfactory nucleus, cerebral cortex (layers I and IV), pyriform cortex, hippocampus (strata radiatum and oriens), amygdaloid complex (central and basolateral nuclei), cerebellar cortex (molecular layer), dorsal cochlear nucleus, nucleus spinal tract of the trigeminal nerve, and dorsal horn of the spinal cord (substantia gelatinosa). Moderate densities of the protein kinase C-like immunoreaction were seen in the cerebral cortex (layers II, III, V, and VI), olfactory bulb (internal granular layer), caudate putamen, nucleus accumbens, medial forebrain bundle, dentate gyrus, thalamus (lateral, ventrolateral, and mediodorsal nuclei), amygdaloid complex (basomedial, anterolateral, centrolateral, and posteromedial nuclei), entorhinal cortex, substantia nigra, interpeduncular nucleus, deep cerebellar nuclei, and lateral vestibular nucleus. Moderately low densities of the immunoreaction were seen in the deepest layer of the frontal cortex, claustrum, thalamus (ventral and medial part of the medial nuclei), rhomboid nucleus, reunient nucleus, hypothalamus (arcuate and ventromedial nuclei), medial geniculate body, superior colliculus, pontine nucleus, vestibular nuclei (superior and medial nuclei), pyramidal tract, and solitary tract nucleus. The lowest immunoreactivity was present in the other regions of the lower brain stem and the white matter, such as the corpus callosum, capsula interna, and medial forebrain bundle.

The density of the protein kinase C-like immunoreactivity is illustrated in the series of frontal-sectional maps extending from the olfactory bulb to spinal cord (Figs. 2 and 3, right column).

\section{Distribution of phorbol ester-binding sites}

Phorbol ester-binding sites were studied in the sections adjacent to the immunostained sections. The distribution of ${ }^{3} \mathrm{H}-\mathrm{PDBu}$ binding sites is shown in Figure 4 (left column) and compared with that of protein kinase C-like immunoreactivity (right column). High grain density of ${ }^{3} \mathrm{H}$-PDBu binding and dense protein kinase C-like immunoreactivity were seen in the cerebral cortex, hippocampus, substantia nigra, and cerebellar cortex. In general, the distribution of ${ }^{3} \mathrm{H}-\mathrm{PDBu}$ binding sites agreed with that of protein kinase $\mathrm{C}$-like immunoreaction.

\section{Distribution of perikarya containing protein kinase C-like immunoreactive material}

Protein kinase $\mathrm{C}$-like immunorcactivity characterized 2 types of perikarya.

karya (type A) (O) are indicated on the right-hand side of the diagram (rostral; $A$ to caudal; $D$ ). 


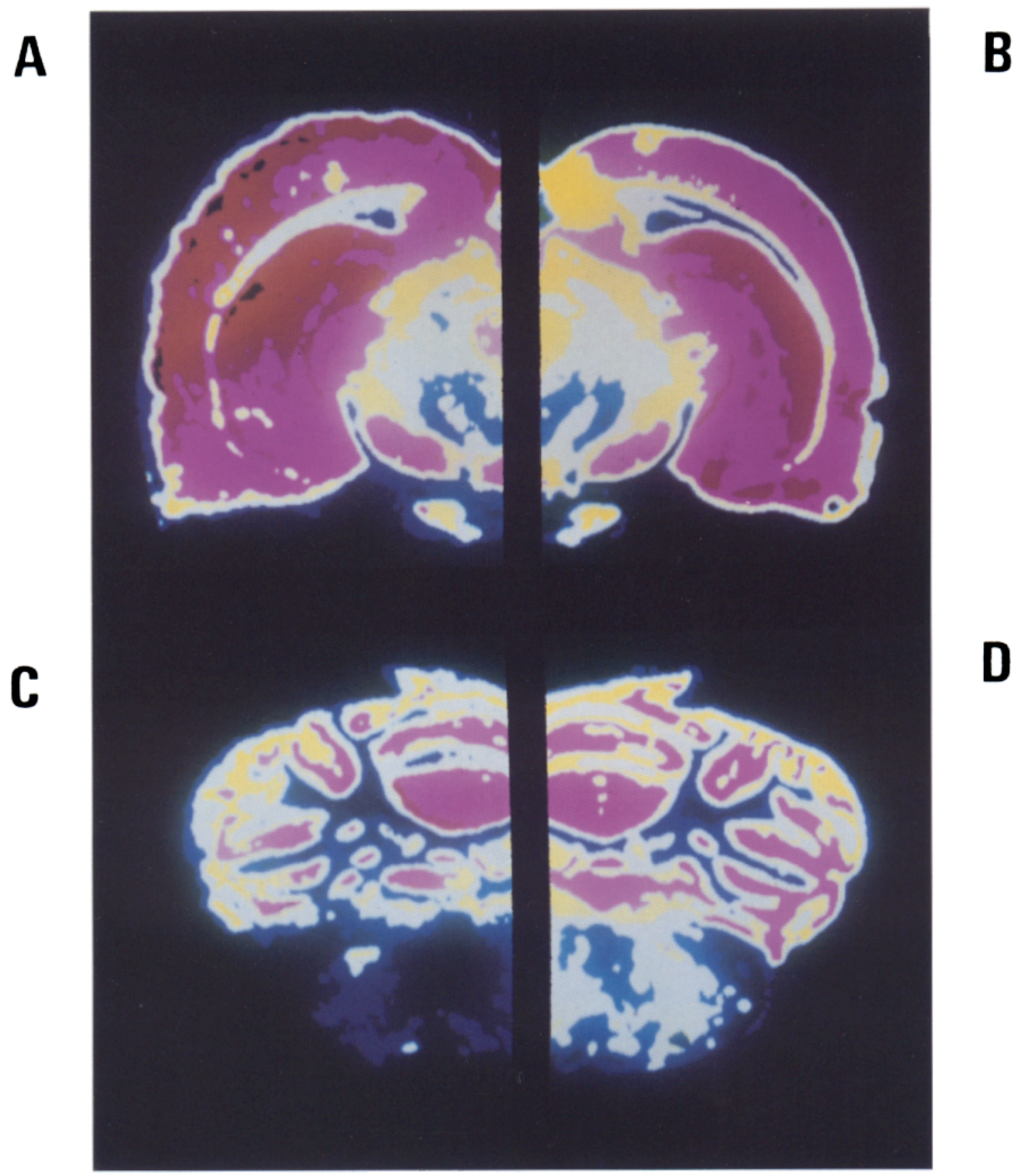

Figure 4. Comparison of the distribution of protein kinase C-like immunoreactivity and phorbol ester-binding sites in the frontal sections of the rat brain. Protein kinase C-like immunoreactivity was localized by peroxidase-antiperoxidase immunohistochemistry $(B, D)$ and phorbol esterbinding sites are shown in the autoradiogram of ${ }^{3} \mathrm{H}-\mathrm{PDBu}$ (phorbol 12,13-dibutyrate) binding $(A, C)$. The color images of the autoradiogram roughly correspond to that of immunoreactivity in the section at the level of midbrain $(A, B)$ and the cerebellum $(C, D)$ but not of the lower brain stem (bottom). Relative density of both the autoradiogram and the immunoreactivity is shown according to the color table (highest density, red; lowest density, black).

Type A perikarya are characterized by the dense immunoreactivity in the cytoplasm. Some of these neurons have immunoreactive dendrites that were traced to some distance. The nucleus of these perikarya usually have poor immunoreactivity. This type of perikarya was seen in the following areas: cerebral cortex (layers IV and VI, particularly in the parietal cortex) (Fig. 5 ), caudate putamen (Fig. 6, $A, B$ ), hippocampus (pyramidal cells) (Fig. 6, $C, D$ ), amygdaloid complex (central and basolateral nuclei) (Fig. 7), medial and lateral geniculate nuclei, superior colliculus (superficial gray layer), cerebellar cortex (Purkinje cells; Fig. 8), dorsal cochlear nucleus (superficial layer) (Fig. 9A), thalamus (lateral, medial, and ventral nuclei) (Fig. 9, $B, C$ ), spinal tract of the trigeminal nerve, and dorsal horn of the spinal cord.

Type $B$ perikarya have dense immunoreactivity on the perikaryal membrane but weak immunoreactivity in the cytoplasm. These perikarya were difficult to distinguish from unstained 

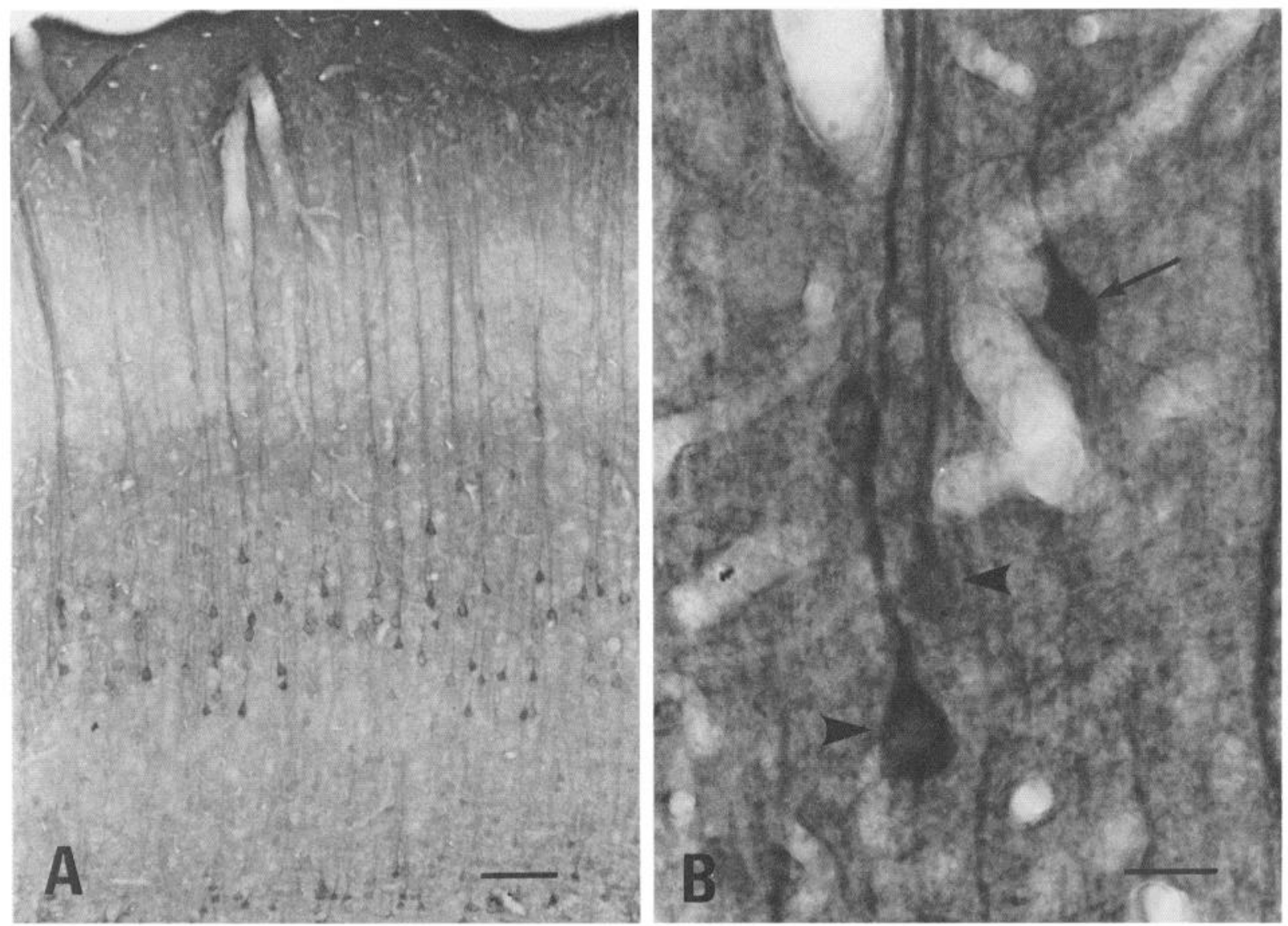

Figure 5. Protein kinase C-like immunoreactivity in frontal section of cerebral cortex as demonstrated by peroxidase-antiperoxidase immunohistochemistry. $A$, Dense immunoreaction in layers I, IV, and VI as demonstrated by the peroxidase-antiperoxidase technique. Pyramidal cells are seen with long apical dendrites extending vertically across layers IV-II. Scale bar, $100 \mu \mathrm{m} . \times 25$. B, Immunoreactive pyramidal cells. Both perikarya and dendrites of the pyramidal cells (arrowheads) are strongly immunostained, but the nuclei are weakly stained. Multipolar medium-sized cell (arrow) is also seen in this layer. Scale bar, $20 \mu \mathrm{m} . \times 160$.

perikarya located in the area densely packed with the immunoreactive neuropils. This type of perikarya was distinctly seen in the following areas: the pyriform cortex (Fig. 7), caudate putamen,and molecular layer of the cerebellar cortex (basket cells and stellate cells) (Fig. 8).

These 2 types of protein kinase $\mathrm{C}$-like immunoreactive perikarya were distributed from rostral to caudal regions of the rat brain. The location of perikarya (type A) in the rat brain is presented in the series of frontal-sectional maps extending from olfactory bulb to spinal cord (Figs. 2 and 3, left column).

\section{Intracellular localization of protein kinase C-like immunoreactivity}

Protein kinase C-like immunoreactivity was found in various neuronal components, such as the perikaryal cytoplasm, dendritic cytoplasm, axons, axon terminals, and perikaryal membrane. Although the nuclei generally showed poor immunoreactivity, some immunoreactive nuclei were seen, whereas immunoreactive material in the nucleolus was not found. The immunostaining of the perikaryal cytoplasm was observed in the areas shown in Figures 1-3 and 5-11. In these regions, the immunostained dendritic cytoplasm was seen together with the immunostained perikaryal cytoplasm. The immunoreactive axon terminals were closely apposed to the cell surface of the unstained nerve cells in the deep cerebellar nuclei (Fig. 10, $A, B$ ), as well as in the lateral vestibular nucleus (Fig. 10,C,D). Stained axons were seen in the granular layer and white matter of the cerebellar cortex (Fig. 11), pyramidal tract (Figs. 2, 3), fornix (Fig. 2), diagonal bundle, anterior commissure (Fig. 2), and dorsal corticospinal tract (Fig. 3). The immunoreactive perikaryal membrane was clearly seen in the molecular layer of the cerebellar cortex (Fig. 8) and pyriform cortex (Fig. 7). However, immunoreactive perikaryal membrane was normally difficult to distinguish from the surrounding nerve terminals or dendrites.

\section{Discussion}

Morphological studies of the localization of protein kinase C have been performed by autoradiography using tumor-promoting phorbol esters (Nagle and Blumberg, 1983; Worley et al., 1986a), which directly activate protein kinase C (Castagna et al., 1982). The highest densities of this autoradiography were localized in the hippocampus, olfactory tubercle, neocortex (layer I), and cerebellar cortex, whereas the lowest density was in the white matter. Image analysis of autoradiogram and immunoreaction revealed that there are a number of similarities between the regional distribution of phorbol ester-binding and of protein kinase C-like immunoreactivity, indicating that the protein kinase C-like immunoreaction obtained here may represent most, if not all, of the enzyme in the rat brain.

More recent analysis of complementary DNA clones has clar- 


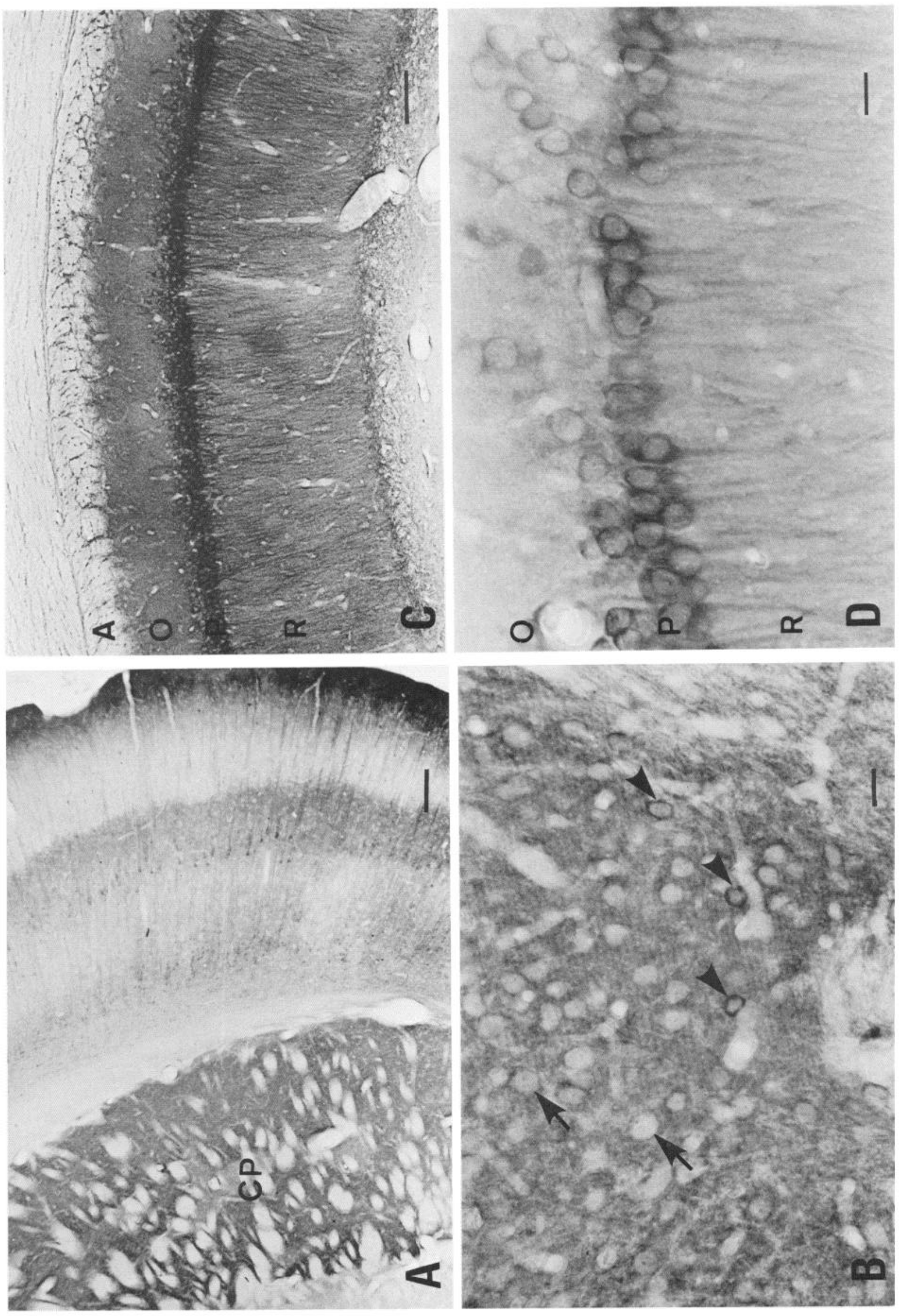

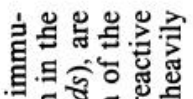

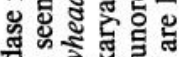

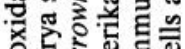

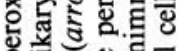

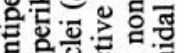

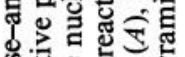

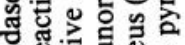

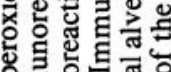

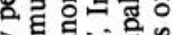

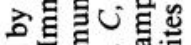

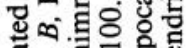

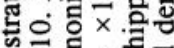

有

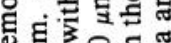

일

ตั율

Q

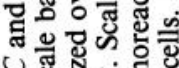

ज्ञ

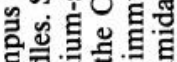

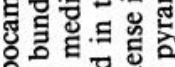

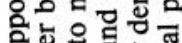

을

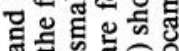

की

당

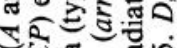

प्र

대의 $x$

颀

2. 范要。

密

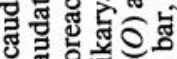

응

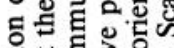

氙需密

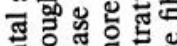

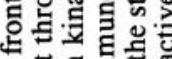

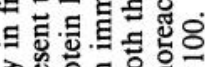

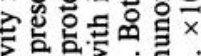

解鸟

언.

엉

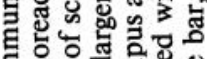

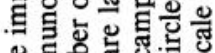

ข

U.

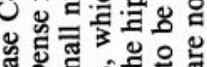
ํำ पर

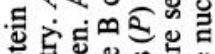

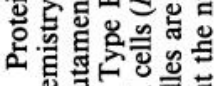

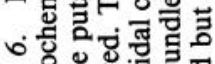

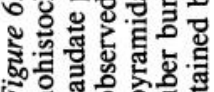



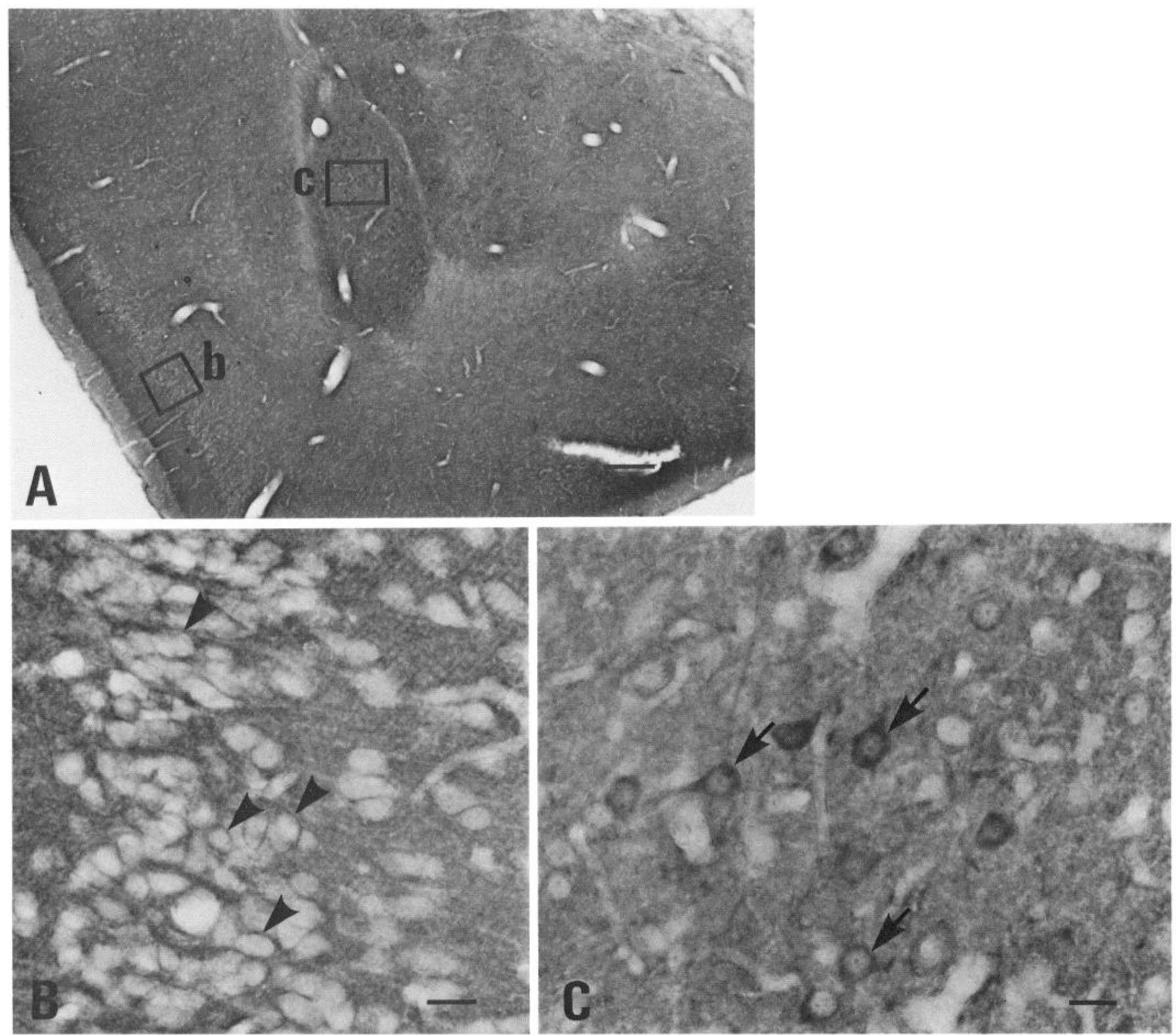

Figure 7. Protein kinase C-like immunoreactivity in frontal section of amygdaloid complex and pyriform cortex as demonstrated by peroxidaseantiperoxidase immunohistochemistry. A, Amygdaloid complex and pyriform cortex. Dense immunoreaction is seen throughout amygdaloid complex and pyriform cortex, the densest immunostaining being present in the basolateral and central nuclei of the amygdaloid complex. Frames indicate areas enlarged in $B$ and $C$. Scale bar, $200 \mu \mathrm{m} . \times 10 . B$, Primary olfactory cortex. The medium-sized to larger cells in this area have immunoreactive perikaryal membrane (arrowheads). Scale bar, $20 \mu \mathrm{m}$. $\times 100$. $C$, Basolateral nucleus of the amygdaloid complex. Immunoreactive perikarya of the medium-sized multipolar cell are seen (arrows). The long immunoreactive dendrite is traced to some distance. Scale bar, $20 \mu \mathrm{m}$. $\times 100$.

ified the presence of multiple species of protein kinase $\mathrm{C}$ in the brain, as mentioned above. The nomenclature of $\alpha, \beta \mathrm{I}, \beta \mathrm{II}$, and $\gamma$ will be used hereafter for the 4 cDNA clones (Coussens et al., 1986; Kikkawa et al., 1987). We demonstrated that the fractions of types I-III are the subspecies of protein kinase $\mathrm{C}$ encoded by $\gamma, \beta$, and $\alpha$-cDNA (Kikkawa et al., 1987).

Very recently, immunochemical analysis of these 3 antibodies has revealed that CKI-33 reacts weakly with enzyme types IIII, whereas CKI-97 reacts strongly and preferentially with type I, which corresponds to the enzyme encoded by $\gamma$ - sequence, and CKII-90 reacts weakly with type II (unpublished observations). Theoretically, a mixture of the 3 antibodies used here can recognize all of the known subspecies of protein kinase $\mathrm{C}$ present in the rat brain. However, CKI-33 and CKII-90 provided poor immunostaining when used alone, while CKI-97 produced intense staining. Thus, the pattern with the 3 monoclonal antibodies was roughly the same as that obtained with CKI-97 alone, suggesting that type I enzyme may be preferentially visualized under the conditions used in the present studies. As will be described in detail in the following papers in this series, type I enzyme has thus far been found only in central nervous tissues.

Recent immunohistochemical studies by Kuo and coworkers, using polyclonal antisera against protein kinase $\mathrm{C}$ (Girard et al., 1985; Shoji et al., 1986; Wood et al., 1986), have demonstrated protein kinase $\mathrm{C}$-like immunoreaction in the presynaptic ter- 


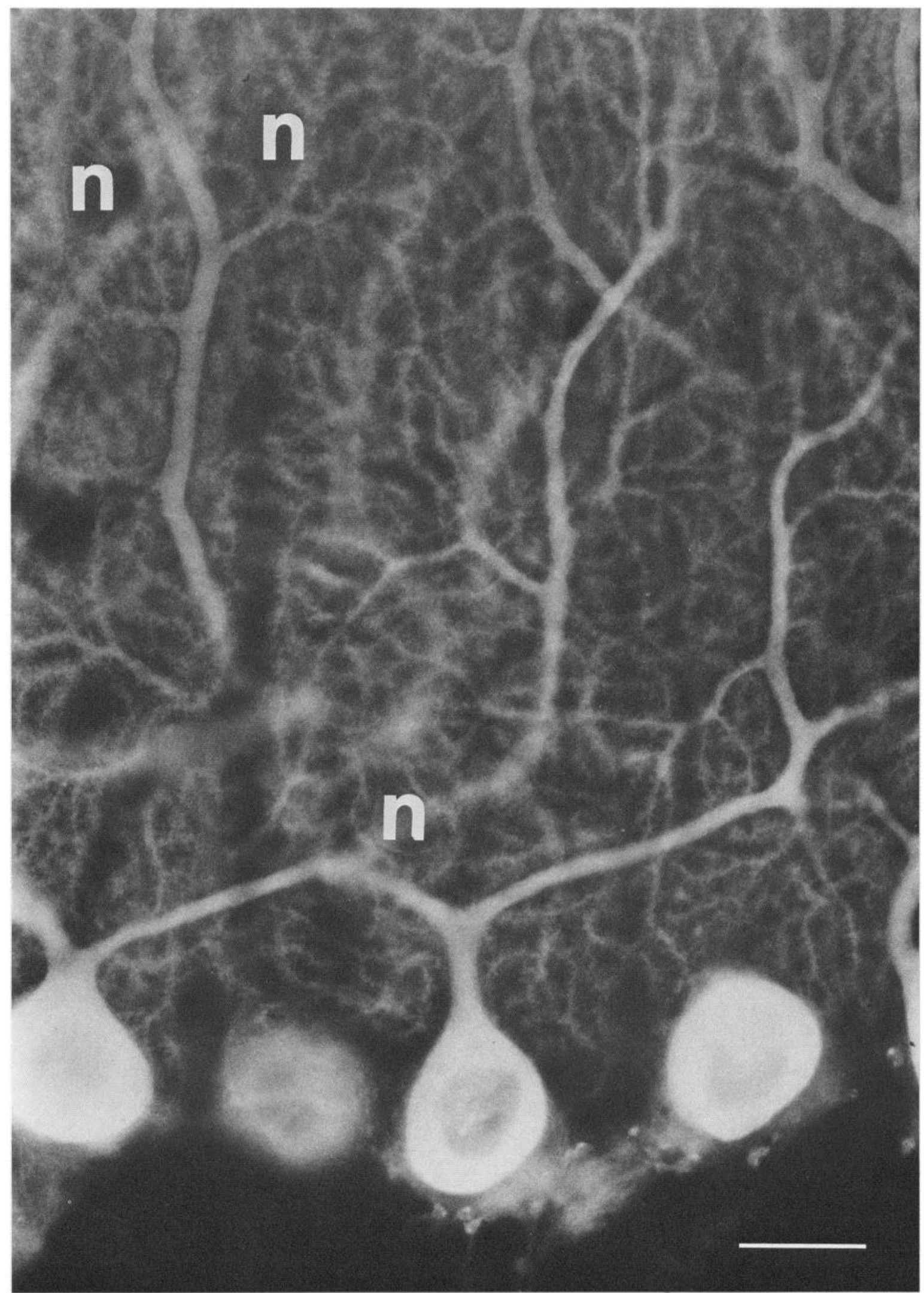

Figure 8. Protein kinase C-like immunoreactivity in sagittal section of cerebellar cortex as demonstrated by the indirect immunofluorescent technique. A unique feature of Purkinje cells is stained. The cytoplasm of all cellular components of Purkinje cells (perikaryon, dendrite, dendritic spine, axon) shows dense immunoreactivity and the nucleus shows weak immunoreactivity, while the nucleole does not. Among the network of dendrites, basket or stellate cells $(n)$ are seen, which show dense immunoreactivity on their cell membranes. Scale bar, $50 \mu \mathrm{m}$. $\times 64$. 

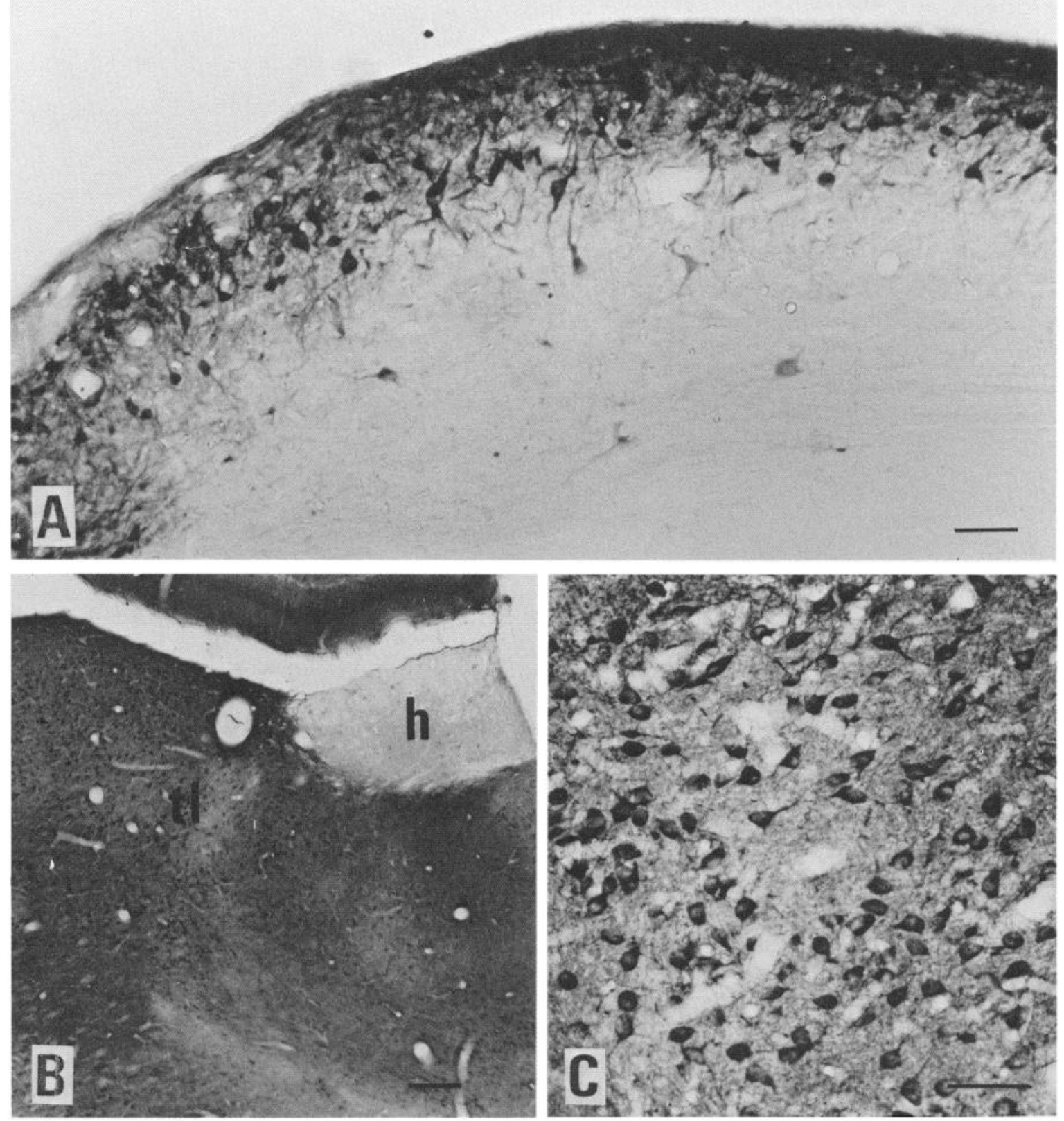

Figure 9. Protein kinase C-like immunoreactivity in frontal section of dorsal cochlear nucleus $(A)$, habenular nucleus $(B)$, and thalamus $(B$, $C)$ as demonstrated by peroxidase-antiperoxidase immunohistochemistry. $A$, Immunoreactive neuropils are seen in the superficial layer of the dorsal cochlear nucleus. A considerable number of the stained multipolar or bipolar medium-sized cells are found in the superficial layer. Scale bar, 50 $\mu \mathrm{m} . \times 25 . B$, Dorsal part of diencephalon. Immunoreactive perikarya are unevenly distributed in various thalamic nuclei. The prominent cluster of highly immunoreactive cells is found in the lateral nucleus $(t l)$. No immunoreactivity is seen in the habenular nuclei $(h)$. Scale bar, $200 \mu \mathrm{m}$. $\times 10$. $C$, Lateral thalamic nucleus. The immunoreactive cells are found to be medium-sized spindle or oval cells with short dendrites. Scale bar, $50 \mu \mathrm{m} . \times 10$.

minals, periphery of the nucleus of cerebral neurons, and oligodendroglia-like cells. These results appear to differ from those obtained in the present studies. The contradictions may result from differences in staining procedures and the characteristics of the antibodies employed. The polyclonal antisera used by Kuo's group were raised against pig brain protein kinase $\mathrm{C}$ and recognized 80 and $67 \mathrm{kDa}$ proteins (Girard et al., 1985, 1986). On the other hand, the 3 monoclonal antibodies used here recognized only the $82 \mathrm{kDa}$ protein in both purified and crude enzyme preparations (Kitano et al., 1987). Most recently, we have obtained antisera against oligopeptides of protein kinase
C subspecies ( $\beta \mathrm{I}$ and $\beta \mathrm{II})$ that react with type II protein kinase C. Immunostaining with these antisera showed that the distribution of type II protein kinase C differs from that of type I in the brain and peripheral tissues of rats. The antisera used in Kuo's laboratory may recognize subtypes other than type I protein kinase $\mathrm{C}$, which is predominantly stained by the monoclonal antibodies employed in the present studies.

Among various protein kinase $\mathrm{C}$-positive neurons, a typical feature is seen in Purkinje cells of the cerebellar cortex, as reported previously (Kitano et al., 1987). A large amount of protein kinase $\mathrm{C}$ is present in somata as well as dendritic trees and 

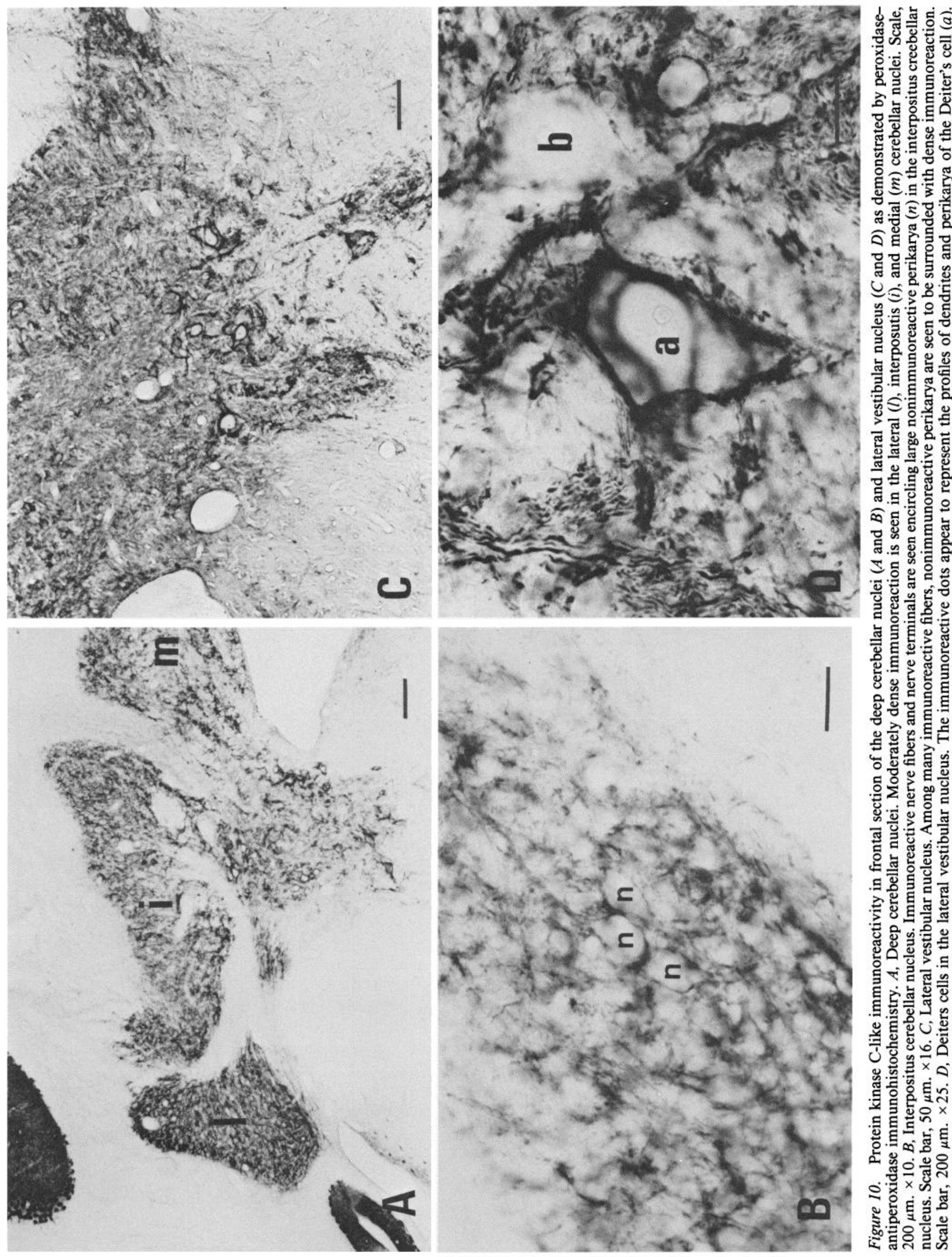

क्ष

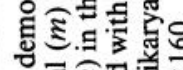
o. ลิ

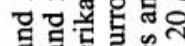
స్

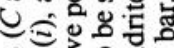
然记 屜出 象官鸟。 . 트 융.

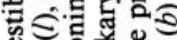

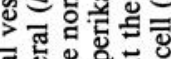

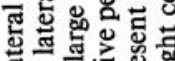
क्ष 욜. की

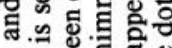
S. 幽造

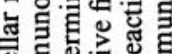

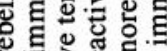
政.

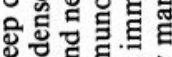
응 过 o

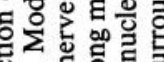
यु.

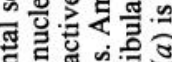

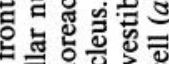
要员

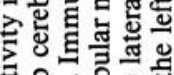

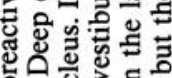
จ 宊焉

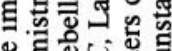

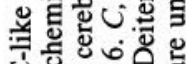
U สํㅇㅇㅊㄹ

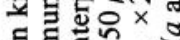

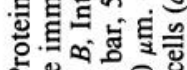

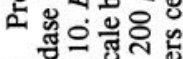
. $\times 1 \times$ 울

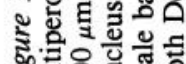

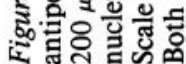




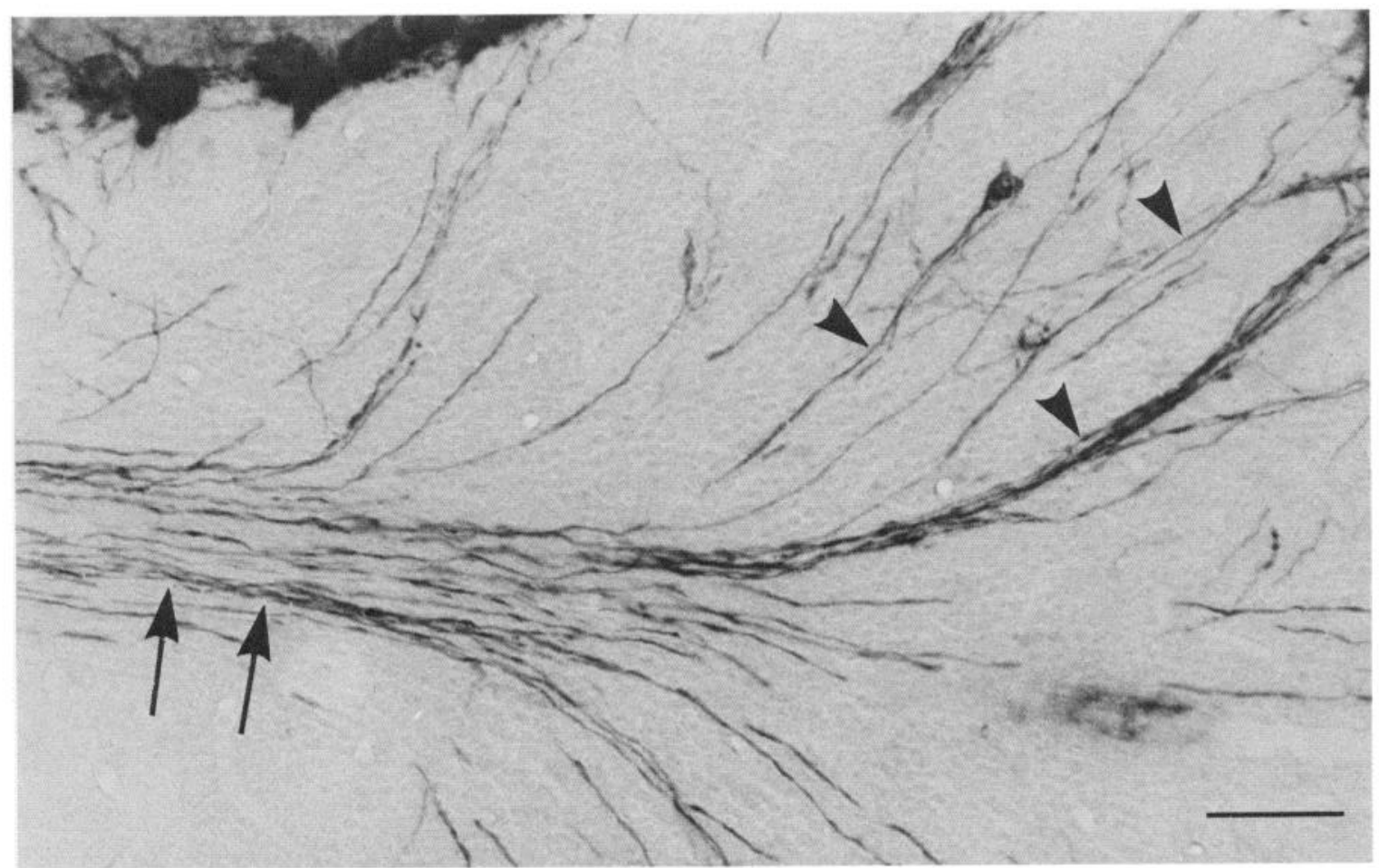

Figure 11. Protein kinase C-like immunoreactivity in a sagittal section of the granular layer of cerebellar cortex as demonstrated by peroxidaseantiperoxidase immunohistochemistry. Immunoreactive axons (arrowheads) of Purkinje cells are present in the granular layer with fine varicosities, while granule cells are not stained. The immunoreactive axons, seen running into the fiber bundle, run parallel with each other through the white matter (arrows). Scale bar, $50 \mu \mathrm{m}$.

many dendritic spines of Purkinje cells. The antiserum against cGMP-dependent protein kinase also stains Purkinje cells (De Camilli et al., 1984). The monoclonal antibodies against protein kinase $\mathrm{C}$ did not, however, react with cGMP-dependent protein kinase, and thus the present immunostaining does not appear to represent cGMP-dependent protein kinase (Kitano et al., 1987).

Kuo and coworkers (Girard et al., 1986; Wood et al., 1986) have also proposed that protein kinase $\mathrm{C}$-like immunoreactivity is mainly associated with the presynaptic components, and not with perikaryal cytoplasm. In contrast, the present studies demonstrate protein kinase $\mathrm{C}$-like immunoreactivity in many axon terminals and perikaryal cytoplasm, as cytoplasmic enzyme can be recognized by the monoclonal antibodies used under appropriate staining conditions. The involvement of protein kinase $\mathrm{C}$ in presynaptic neural functions has been proposed from the physiological findings that activation of protein kinase $\mathrm{C}$ enhances ACh release from ileal strips (Tanaka et al., 1984) and striatal slices (Tanaka et al., 1986), noradreneline release from the sinus node (Shuntoh and Tanaka, 1986), and dopamine release from cultured neurons (Zurgil and Zisapel, 1985). The present observations may provide a morphological basis for protein kinase $\mathrm{C}$ in the regulation of neurotransmitter release. Purkinje cells innervate the lateral vestibular nucleus and the deep cerebellar nuclei (Obata et al., 1967), and the immunoreactive terminals are attached to Deiter's cells in the lateral vestibular nucleus and also to the neurons of the deep cerebellar nuclei. Immunoreactive nerve terminals are also seen in the neuropils of the substantia nigra and caudate putamen.

In the hippocampus, protein kinase $\mathrm{C}$ has been suggested to be associated with the generation of long-term potentiation (LTP), as LTP elevates the phosphorylation of protein $F 1$, which is a substrate of protein kinase C (Akers et al., 1985, 1986; Malenka et al., 1986). The present results reveal that a large amount of protein kinase $\mathrm{C}$ is contained in the hippocampal cortex, especially in perikarya and apical dendrites of the pyramidal cell, which is a postsynaptic component of the site where LTP has been thoroughly characterized. This suggests that protein kinase $\mathrm{C}$ is involved in the generation of LTP in the postsynaptic component, in addition to presynaptic control of transmitter release in the hippocampus (Malenka et al., 1986).

The distribution of protein kinase C-like immunoreactivity does not always correspond to that of any of the classical neurotransmitters such as monoamines, $\mathrm{ACh}$, amino acids, and neuropeptides. It also differs from that of other second-messenger systems [adenylate cyclase, guanine nucleotide-binding protein $\left(\mathrm{G}_{0}\right)$ ] (Worley et al., 1986b, c). There are some differences between the localization of guanine nucleotide-binding protein and that of protein kinase C-like immunoreactivity. For example, pyramidal cells in the hippocampus are not stained with antiserum against guanine nucleotide-binding protein; protein kinase $\mathrm{C}$, however, is present in the pyramidal cells, where the immunoreaction is seen in the thin cytoplasm but not in the large nucleus. These observations suggest that protein kinase $\mathrm{C}$ is not always associated with guanine nucleotide-binding protein.

Worley et al. (1987) have also observed that the distribution of radioactive inositol 1,4,5-trisphosphate $\left(\mathrm{IP}_{3}\right)$ binding is similar to that of protein kinase $C$ in the cerebral and cerebellar cortices but not in the substantia gelatinosa of spinal cord. We suggest that the $\mathrm{IP}_{3}$ branch may play a prominent role in the cerebellum, while in the substantia gelatinosa of spinal cord, the 
action of protein kinase $\mathrm{C}$ may predominate. However, intense protein kinase $\mathrm{C}$-like immunoreactivity was observed in the dendritic spines of Purkinje cells, which possess a subsurface specialization of the endoplasmic reticulum, an intracellular source of calcium (Henkart et al., 1976; Fifkova et al., 1983); this suggests prominent roles for protein kinase $\mathrm{C}$ and $\mathrm{IP}_{3}$ in the cerebellum.

In conclusion, the present studies may provide morphological evidence for the possible involvement of protein kinase $\mathrm{C}$ in both presynaptic and postsynaptic functions. It must be recognized, however, that the presence of immunonegative areas or immunonegative subcellular components, such as the corpus callosum or nucleus, does not reflect the absence of protein kinase $\mathrm{C}$, especially of other types of this enzyme family.

\section{Appendix}

Abbreviations used in the figures

$a b l$, nucleus amygdaloideus basalis, pars lateralis

$a b m$, nucleus amygdaloideus basalis, pars medialis

$a c$, nucleus amygdaloideus centralis

aco, nucleus amygdaloideus corticalis

ala, nucleus amygdaloideus lateralis, pars anterior

alp, nucleus amygdaloideus lateralis, pars posterior

$a m b$, nucleus ambiguus

$B C I$, brachium colliculi inferioris

$C C$, crus cerebri

$C C A$, corpus callosum

$C E$, cortex entorhinalis

cgm, nucleus centralis corporis geniculati medialis

$\mathrm{cl}$, claustrum

cod, nuclcus cochlearis dorsalis

cov, nucleus cochlearis ventralis

$c p$, nucleus caudate putamen

$c t$, nucleus corporis trapezoidei

$\mathrm{cu}$, nucleus cuneatus

$\mathrm{cul}$, nucleus cuneatus lateralis

$d c g l$, nucleus dorsalis corporis geniculati lateralis

$F C$, fasciculus cuneatus

$F H$, fimbria hippocampi

$F L M$, fasciculus longitudinalis medialis

$F M T$, fasciculus mamillothalamicus

$G C C$, genu corporis callosi

$g r$, nucleus gracilis

lc, locus coeruleus

$L L$, lemniscus lateralis

$l l r$, nucleus lemnisci lateralis rostralis

$l l v$, nucleus lemnisci lateralis ventralis

$L M$, lemniscus medialis

$L M I O$, lamina medullaris interna bulbi olfactorii

$\mathrm{mi}$, massae intercalatae

$n a$, nucleus arcuatus

nco, nucleus commissuralis

nic, nucleus intercalatus

$n p V$, nucleus sensorius principalis nervi trigemini

nro, nucleus raphe obscurus

$n r p$, nucleus reticularis paramedianus

nrpo, nucleus raphe pontis

$n t d$, nucleus tegmenti dorsalis

ntdl, nucleus tegmenti dorsalis lateralis

$n t s$, nucleus tractus solitarii

$n t v$, nucleus tegmenti ventralis

$n t V$, nucleus tractus spinalis nervi trigemini

$n t V d$, nucleus tractus spinalis nervi trigemini, pars dorsomedialis

$n V$, nucleus originis nervi trigemini

$n V I$, nucleus originis nervi abducentis

$n X I I$, nucleus originis nervi hypoglossi oad, nucleus olfactorius anterior, pars dorsalis

$o a e$, nucleus olfactorius anterior, pars externa

oal, nucleus olfactorius anterior, pars lateralis

oam, nucleus olfactorius anterior, pars medialis

$O I$, oliva inferior

os, nucleus olivaris superior

$p$, nucleus pretectalis

$P$, tractus corticospinalis

PCMA, pedunculus corporis mamillaris

$P C S$, pedunculus cerebellaris medius

$p h$, nucleus prepositus hypoglossi

$r l$, nucleus reticularis lateralis

$S$, subiculum

$s g$, nucleus suprageniculatus facialis

$s g V$, nucleus tractus spinalis nervi trigemini, substantia gelatinosa

snc, substantia nigra, pars compacta

$s n r$, substantia nigra, pars reticularis

$S T$, stria terminalis

$T O$, tractus opticus

$t o l$, nucleus tractus optici, pars lateralis

$T O L$, tractus olfactorius lateralis

tom, nucleus tractus optici, pars medialis

$T R S$, tractus rubrospinalis

$T S V$, tractus spinalis nervi trigemini

$t u$, tuberculum olfactorium

$t v$, nucleus ventralis

$v c g l$, nucleus ventralis corporis geniculati lateralis

$v l$, nucleus vestibularis lateralis

$v m$, nucleus vestibularis medialis

$v s$, nucleus vestibularis superior

$V I I$, nervus facialis

$V M$, nervus trigeminus, radix motoria

$V S$, nervus trigeminus, radix sensoria

\section{References}

Akers, R. F., and A. Routtenberg (1985) Protein kinase C phosphorylates a $47 \mathrm{Mr}$ protein $(\mathrm{F} 1)$ directly related to synaptic plasticity. Brain Res. 334: 147-151.

Akers, R. F., D. M. Lovinger, P. A. Colley, D. J. Linden, and A. Routtenberg (1986) Translocation of protein kinase C activity may mediate hippocampal long-term potentiation. Science 231: 587-589.

Castagna, M., Y. Takai, K. Kaibuchi, K. Sano, U. Kikkawa, and Y. Nishizuka (1982) Distribution activation of calcium-activated, phospholipid-dependent protein kinase by tumor-promoting phorbol esters. J. Biol. Chem. 257: 7847-7851.

Coussens, L., P. J. Parker, L. Rhee, T. L. Yang-Feng, E. Chen, M. D. Waterfield, U. Francke, and A. Ullrich (1986) Multiple, distinct forms of bovine and human protein kinase $C$ suggest diversity in cellular signaling pathways. Science 233: 859-866.

De Camilli, P., P. E. Miller, P. Levitt, U. Walter, and P. Greengard (1984) Anatomy of cerebellar Purkinje cells in the rat determined by a specific immunohistochemical marker. Neuroscience 11:761817.

Fifkova, E., J. A. Markham, and R. J. Delay (1983) Calcium in the spines in the dentate molecular layer. Brain Res. 266: 163-168.

Girard, P. R., G. J. Mazzei, J. G. Wood, and J. F. Kuo (1985) Polyclonal antibodies to phospholipid/ $\mathrm{Ca}^{2+}$-dependent protein kinase and immunocytochemical localization of the enzyme in rat brain. Proc. Natl. Acad. Sci. USA 82: 3030-3034.

Girard, P. R., G. J. Mazzei, J. G. Wood, and J. F. Kuo (1986) Immunological quantitation of phospholipid/ $\mathrm{Ca}^{2+}$-dependent protein kinase and its fragment. J. Biol. Chem. 261:370-375.

Henkart, M., D. M. D. Landis, and T. S. Reese (1976) Similarity of junctions between plasma membranes and endoplasmic reticulum in muscle and neurons. J. Cell Biol. 70: 338-347.

Huang, K. P., H. Nakabayashi, and F. L. Huang (1986) Isozymic forms of rat brain $\mathrm{Ca}^{2+}$-activated and phospholipid-dependent protein kinase. Proc. Natl. Acad. Sci. USA 83: 8535-8539.

Kikkawa, U., Y. Takai, R. Minakuchi, S. Inohara, and Y. Nishizuka (1982) Calcium-activated, phospholipid-dependent protein kinase 
from rat brain. Subcellular distribution, purification, and properties. J. Biol. Chem. 257: 13341-13348.

Kikkawa, U., M. Go, J. Koumoto, and Y. Nishizuka (1986) Rapid purification of protein kinase $\mathrm{C}$ by high performance liquid chromatography. Biochem. Biophys. Res. Commun. 135: 636-643.

Kikkawa, U., Y. Ono, K. Ogita, T. Fujii, Y. Asaoka, K. Sekiguchi, Y. Kosaka, K. Igarashi, and Y. Nishizuka (1987) Identification of the structures of multiple subspecies of protein kinase $C$ expressed in rat brain. FEBS Lett. 217: 227-231.

Kishimoto, A., Y. Takai, T. Mori, U. Kikkawa, and Y. Nishizuka (1980) Activation of calcium and phospholipid-dependent protein kinase by diacylglycerol, its possible relation to phosphatidyl inositol turnover. J. Biol. Chem. 255: 2273-2276.

Kitano, T., T. Hashimoto, U. Kikkawa, K. Ase, N. Saito, C. Tanaka, Y. Ichimori, K. Tsukamoto, and Y. Nishizuka (1987) Monoclonal antibodies against rat brain protein kinase $\mathrm{C}$ and their application to immunocytochemistry in nervous tissues. J. Neurosci. 7: 1520-1527.

Knopf, J. L., M.-H. Lee, L. A. Sultzman, R. W. Kriz, C. R. Loomis, R. M. Hewick, and R. M. Bell (1986) Cloning and expression of multiple protein kinase $C$ cDNAs. Cell 46: 491-502.

Kuo, J. F., R. G. G. Andersson, B. C. Wise, L. Mackerlova, I. Salomonsson, N. L. Brackett, N. Katoh, M. Shoji, and R. W. Wrenn (1980) Calcium-dependent protein kinase: Widespread occurrence in various tissues and phyla of the animal kingdom and comparison of effects of phospholipid, calmodulin, and trifluoperazinc. Proc. Natl. Acad. Sci. USA 77: 7039-7043.

Makowske, M., M. J. Birnbaum, R. Ballester, and O. M. Rosen (1986) A cDNA encoding protein kinase $C$ identifies two species of mRNA in brain and $\mathrm{GH}_{3}$ cells. J. Biol. Chem. 261: 13389-13392.

Malenka, R. C., D. V. Madison, and R. A. Nicoll (1986) Potentiation of synaptic transmission in the hippocampus. Nature 321: 175-177.

Minakuchi, R., Y. Takai, B. Yu, and Y. Nishizuka (1981) Widespread occurrence of calcium-activated, phospholipid-dependent protein kinase in mammalian tissues. J. Biochem. (Tokyo) 89: 1651-1654.

Nagle, D. S., and P. M. Blumberg (1983) Regional localization by light microscopic autoradiography of receptors in mouse brain for phorbol ester tumor promoters. Cancer Lett. 18: 35-40.

Nishizuka, Y. (1984a) The role of protein kinase C in cell surface signal transduction and tumor promotion. Nature 308: 693-698.

Nishizuka, Y. (1984b) turnover of inositol phospholipids and signal transduction. Science 255: 1365-1370.

Nishizuka, Y. (1986) Studies and perspectives of protein kinase C. Science 233: 305-312.

Obata, K., M. Ito, R. Ochi, and N. Sato (1967) Pharmacological properties of the postsynaptic inhibition by Purkinje cell axons and the action of $\gamma$-aminobutyric acid on Deiters neurones. Exp. Brain. Res. 4: 43-57.

Ohno, S., H. Kawasaki, S. Imajoh, K. Suzuki, M. Inagaki, H. Yokokura, T. Sakoh, and H. Hidaka (1987) Tissue-specific expression of three distinct types of rabbit protein kinase C. Nature 325: 161-166.

Ono, Y., T. Kurokawa, K. Kawahara, O. Nishimura, R. Marumoto, K. Igarashi, Y. Sugino, U. Kikkawa, K. Ogita, and Y. Nishizuka (1986a)
Cloning of rat brain protein kinase $\mathrm{C}$ complementary DNA. FEBS Lett. 203: 111-115.

Ono, Y., T. Kurokawa, T. Fujii, K. Kawahara, O. Nishimura, K. Igarashi, U. Kikkawa, K. Ogita, and Y. Nishizuka (1986b) Two types of complementary DNAs of rat brain protein kinase $\mathrm{C}$, heterogeneity determined by alternative splicing. FEBS Lett. 206: 347-352.

Ono, Y., U. Kikkawa, K. Ogita, T. Fujii, T. Kurokawa, Y. Asaoka, K. Sekiguchi, K. Ase, K. Igarashi, and Y. Nishizuka (1987) Expression and properties of two types of protein kinase $C$ determined by alternative splicing from a single gene. Science 236: 1116-1120.

Parker, P. J., L. Coussens, N. Totty, L. Rhee, S. Young, E. Chen, S. Stabel, M. D Waterfield, and A. Ullrich (1986) The complete primary structure of protein kinase $\mathrm{C}$ - the major phorbol ester receptor. Science 233: 853-859.

Shoji, M., P. R. Girard, G. J. Mazzei, W. R. Vogler, and J. F. Kuo (1986) Immunocytochemical evidence for phorbol ester-induced protein kinase C translocation in HL60 cells. Biochem. Biophys. Res. Commun. 135: 1144-1149.

Shuntoh, H., and C. Tanaka (1986) Activation of protein kinase C potentiates norepinephrine release from sinus node. Am. J. Physiol. 251: C833-C840.

Takai, Y., A. Kishimoto, U. Kikkawa, T. Mori, and Y. Nishizuka (1979) Unsaturated diacylglycerol as a possible messenger for the activation of calcium-activated, phospholipid-dependent protein kinase system. Biochem. Biophys. Res. Commun. 90: 1218-1224.

Tanaka, C., K. Taniyama, and M. Kusunoki (1984) A phorbol ester and $\mathrm{A} 23187$ act synergistically to release acetylcholine from the guinea pig ileum. FEBS Lett. 175: 165-169.

Tanaka, C., H. Fujiwara, and Y. Fujii (1986) Acetylcholine release from guinea pig caudate slices evoked by phorbol ester and calcium. FEBS Lett. 195: 129-134.

Wood, J. G., P. R. Girard, G. J. Mazzei, and J. F. Kuo (1986) Immunocytochemical localization of protein kinase $C$ in identified neuronal compartments of rat brain. J. Neurosci. 6: 2571-2577.

Worley, P. F., J. M. Baraban, and S. H. Snyder (1986a) Heterogeneous localization of protein kinase $C$ in rat brain: Autoradiographic analysis of phobol ester receptor binding. J. Neurosci. 6: 199-207.

Worley, P. F., J. M. Baraban, E. B. De Souza, and S. H. Snyder (1986b) Mapping second messenger systems in the brain: Differential localization of adenylate cyclase and protein kinase C. Proc. Natl. Acad. Sci. USA 83: 4053-4057.

Worley, P. F., J. M. Baraban, C. Van Dop, E. J. Neer, and S. H. Snyder (1986c) $G_{0}$, a guanine nucleotide-binding protein: Immunohistochemical localization in rat brain resembles distribution of second messenger systems. Proc. Natl. Acad. Sci. USA 83: 4561-4565.

Worley, P. F., J. M. Baraban, J. S. Colvin, and S. H. Snyder (1987) Inositol triphosphate receptor localization in brain: Variable stoichiometry with protein kinase C. Nature 325: 159-161.

Zurgil, N., and N. Zisapel (1985) Phorbol ester and calcium act synergistically to enhance neurotransmitter release by brain neurons in culture. FEBS Lett. 185: 257-261. 